\title{
The Effect of a Problem Centered Learning on Student's Mathematical Critical Thinking
}

\author{
Lidya Putri Apriliana ${ }^{1 *}$, Isnaini Handayani ${ }^{2)}$, Subhan Ajiz Awalludin ${ }^{2)}$ \\ 1) Sabilina Islamic School, Bekasi, INDONESLA \\ ${ }^{2)}$ Department of Mathematics Education, Universitas Mubammadiyah Prof. DR. HAMKA, Jakarta, \\ INDONESIA \\ *Corresponding author: apriliana.lidyaputri@gmail.com
}

\begin{abstract}
Since Indonesian students' critical thinking skills in junior high school is still in unexpected level, it should be improved through teaching and learning process. The objective of the study is finding out the influence of problem centered learning approach toward students' mathematical critical thinking ability. Every student should bave mathematical critical thinking skills to make mathematics lessons are easier. Using the critical thinking skills will help students improving problem solving skills. However, the current critical thinking ability of junior bigh school students is still low. This research used quasi experimental design with Static Group Comparation type. The research sample consisted of two classes with each class of 35 students. The research instrument consists of six questions which indicate a mathematical critical thinking ability. Data analysis of this study used the Mann-Whitney test. The results of the study indicate that there is an effect of the problem-centered learning approach on the students' mathematical critical thinking ability with testing criteria is high.
\end{abstract}

Keywords: Problem-Centered Learning, Mathematical Critical Thinking, Problem Solving Skills

Received: $2^{\text {nd }}$ July 2019, Revised: $17^{\text {th }}$ August 2019, Accepted: $18^{\text {th }}$ August 2019

\section{Introduction}

Mathematics is a scientific discipline that involves the development of thinking pattern and the organization of logic. A well-formed pattern of thinking will create reasoning and logical thinking. Learning mathematics requires the reasoning and thinking ability. This is in accordance with the statement of Hendryawan, Yusuf, and Wachyar (2017) that students who succeed in learning mathematics are expected to have good critical thinking ability. Besides that Aizikovitsh-Udi \& Cheng (2015) also stated that the benefit of critical thinking is lifelong, it supports students in the regulation of their study skills and subsequently it empowers individual to contribute creatively. Therefore, one of the high-level of thinking abilities that can be developed in mathematics learning is mathematical critical thinking ability.

In learning mathematics, teachers are expected to develop students' critical thinking skills. Minister of National Education Regulation (Permendiknas, 2007) states that one of teachers' essential competencies is to improve students' skills and to actualize them in order to faced various situations. This competency leads teacher to provide various learning activities that encourage students to develop and to actualize their critical 
thinking skills. Moreover, problem-solving tasks are used to improve problem solving skills. Therefore, each student is expected to have critical thinking skills to support the learning process in mathematics.

Mathematics learning given in every educational stage is developing students' critical thinking skills as well as their cognitive development. The cognitive development of students at each level of education is different. A middle school student considered as adult, is expected to think critically (Setiawan \& Royani, 2013). This is confirmed by Minister of National Education Regulation (Permendiknas, 2006) which sets applicable competency standards. In addition, mathematics at junior high level should improve students' logical, analytical, systematic, critical, creative abilities andcooperative.

This is in accordance with the $21^{\text {st }}$ century, education has an important role in facing the development challange. At present, we have entered the industrial revolution 4.0. Along with the development of this era, educators are the most important element in education system. This is what requires educators to realize the learning process based on six skills of $21^{\text {st }}$ century. One of these skills is critical thinking ability. Critical thinking ability and problem solving are considered as a fundamental ability in $21^{\text {st }}$ century learning. Critical thinking is a rational thinking activity to solve the problems better (Dewi, 2015). However, in fact, mathematical critical thinking ability of junior high school students in Indonesia is still in unexpected level.

The study conducted in one of the junior high schools showed that the low level of students' critical thinking ability (Noer as cited by Hendryawan et al., 2017). This study was done in one of junior high schools which states that an enhancement in critical thinking ability of high-level students' is at a moderate level (0.51) and an enhancement in critical thinking ability of the middle-level students' is at a low level (0.29). In addition, the same result was obtained by Putri, Darmawijoyo, \& Susanti (2018) which states the percentage of students who have critical thinking ability in a good category by $36 \%$, satisfactory category by $9 \%$, in less than satisfactory by $45 \%$, and very less satisfactory by $9 \%$, and there are no students who have the critical thinking ability in a very good category.

The low level of mathematical critical thinking ability will influence the students' cognitive development. Students tend to be incapable of solving the problem given by the teacher, so that the students can not effectively participate in teaching and learning activities. Students become a good problem solvers if their mathematical critical thinking skills are well developed. This is in accordance with the idea of Dewanti (2009) that the ability to solve mathematical problems will be well obtained by students if in learning communication occurs between the teacher and students or between students that stimulates the creation of participation. Students are given the opportunity to better understand a mathematical concept from the results of sharing ideas between students. Furthermore, Dewanti (2009) said that through learning activities on interesting problems, students always try to solve problems, prioritize communication, focus on the processes of inquiry and reasoning, and develop confidence in dealing with situations of daily life. Mathematical critical thinking skills of students can be built through the learning process. However, teachers have difficulty choosing an interactive learning approach. This shows that learning mathematics requires a learning approach that meets aspects of student-centered learning. One learning approach that can shape mathematical critical thinking skills is a problem-centered learning approach. The application of the problem-centered learning approach in learning mathematics can prevent the development of basic conceptual errors. This is because problem-centered learning will guide students to construct students' own knowledge, so students will find the basic concepts of the material they are learning. 
Critical thinking is one of the high levels of thinking and can be called as reflective thinking. This is in accordance with the statement of Nuriadin, et al (2015) that someone who uses the reflective thinking will have the ability to identify problems, to choose alternative solutions, to analyze problems and to evaluate solutions, as well as to conclude and to decide the best solution to the problem given.

Based on the four components of critical thinking above, critical thinking ability can be measured by knowing one's perspective on something. Someone who can explain, analyze, generalize, assess and draw conclusion can be said that someone has critical thinking ability. Ennis (2011) suggests that critical thinking is a concept that includes cognitive and meta-cognitive skills, practices and abilities, dispositions and character, logical, reflective, and can make its own decision.

Critical thinking ability does not only build cognitive aspects but also builds other aspects of the learning process. Mathematical critical thinking ability can build students' thinking, so students can draw conclusion to determine the right solution in solving problems, especially in mathematics learning. Learning mathematics will be more effective by presenting real problem.

Real problems in learning mathematics will train students to be able to solve a problem. This can stimulate students to think critically to find alternative solutions and appropriate strategies for the given problems, so students can train themselves to solve a problem properly. Handayani (2015) states that problem solving that appears in mathematics and other contexts should be adjusted to various appropriate strategies in solving problems. This statement shows that a problem should be solved using the appropriate strategy. The way to get the appropriate strategy in solving a problem is to analyze the problem, to think deeply about the important things of the problem, and to find the appropriate concept. Based on this explanation, critical thinking ability can be built through the present of authentic problems.

According to Dewanti (2009), the Problem-Centered Learning (PCL) approach is a learning that always presents mathematical ideas in problem-centered situations. Furthermore, Dewanti (2009) said that this approach is a starting point for learning that gives students the opportunity to identify emerging problems, formulate questions regarding problems, and try to provide alternative solutions. This shows that a problemcentered learning approach can provide opportunities for students to acquire, discover, recognize, and solve problems that originate from students' knowledge or experiences.

This is in line with Jakubowski's opinion that PCL as a learning approach that focuses on the ability of students to construct their own understanding of mathematical concepts (Arsisari, 2018). Student can construct their own knowledge by provision of authentic problems provided in the learning process through the problem centered learning. This shows that problem-centered learning is a learning approach that focuses on authentic problem presentation. Authentic problems are real problems related to mathematics. The presence of authentic problems in mathematics learning can build students' minds and their own knowledge. The problem-solving process will show how much students' mathematical critical thinking ability.

Based on the problems that have been described, focus of problem in this study are whether there is an effect of the problem-centered learning approach to students' mathematical critical thinking ability in junior high School. Therefore, the hypothesis is the problem-centered learning approach is very effective in building students' mathematical critical thinking skills.

\section{Research Methods}

This study used a quasi-experimental method with a static type of comparison group because the research in both classes (experimental and control) were not given a 
pretest and the subjects were not randomly selected. The population of this study is all students in one of junior high school in Jakarta who are registered as students in the even semester of the 2017/2018 academic year. Sampling is done by Probability Sampling with Cluster Random Sampling technique. Then two classes are chosen as the experimental and control classes, each class consisting of 35 students.

The data in this study is collected using instrument of test for students' critical thinking ability mathematically on the topic of Pythagorean Theorem after a six-meeting teaching process. The instrument has been tested for its validity, reliability, degree of difficulty and differentiation. The expert from content validity is mathematics education lecturer. Figure 1 is a sample questions used to measure students' critical thinking ability in the experimental and control classes.

Table 1. Guidelines for scoring students' mathematical critical thinking ability

1

(Determine the concepts used in problem solving)

$\begin{array}{lll} & & \\ & & \\ \text { problems }\end{array}$
Indicators

2

(Formulate an action (strategy, tactics, or approach) in solving

the

the od,

not

the

way

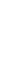

Can give an argument but is wrong in connecting the information provided

Able to give the expected argument but there are still a few mistakes in answering

Able to provide a complete argument with the correct calculation in solving the problem given

\section{4}

(Evaluate the evidence or decisions that have been taken in solving the problem) No Answer

Not provide a correct evaluation, indicated not understand the problem

Can provide evaluation but is wrong in connecting the information provided

Able to provide the expected evaluation but there are still a few mistakes in answering

Able to evaluate according to the expected complete with strengthening considerations in solving the problem given

\section{Seorang arsitek mendesain taman kota dengan bentuk belah ketupat Di sekeliling taman tersebut akan dipasangkan lampu. Jarak setiap tiang lampu yang mengelilingi taman adalah $2 \mathrm{~m}$. Panjang diagonal taman adalah $16 \mathrm{~m}$ dan $12 \mathrm{~m}$. Bagaimana cara menentukan banyak tiang lampu yang diperlukan untuk menerangi taman kota tersebut?}

Figure 1. Sample of the problems given to the students 
Translate of Figure 1:

An architect designed a city park with a rhombus shape. The lights will be installed surrounding park. The distance of each lamp post which through the park is 2 meters. the diagonal length of the park is 16 meters and 12 meters respectively. How to determine the lamppost needed?

Scoring of the answers to the tests requires guidelines to measure mathematical critical thinking ability as shown in Table 1. Calculation of research data using Excel. These results indicate that the data is not normally distributed. Because the data is not normally distributed, the data analysis technique being used is the Mann-Whitney test.

\section{Results and Discussion}

Based on the score of the results of students' mathematical critical thinking ability in the experimental and control classes, the concentration and data size values can be seen in Table 2.

Table 2. Descriptive Statistics Score of Students' Mathematical Critical Thinking Ability of Experimental and Control Classes

\begin{tabular}{ccc}
\hline Statistic & Experiment Class & Control Class \\
\hline Sum & 35 & 35 \\
Mean & 10,40 & 7,11 \\
Variance & 27,54 & 13,69 \\
SD & 5,25 & 3,70 \\
\hline
\end{tabular}

Table 3. Normality Test of Students' Score in Experimental and Control Classes

\begin{tabular}{cccccc}
\hline Class & $\overline{\boldsymbol{X}}$ & $\boldsymbol{s}$ & $\boldsymbol{L}_{\text {count }}$ & $\boldsymbol{L}_{\text {table }}$ & Conclusion \\
\hline Experiment & 10,4 & 5,248 & 0,1133 & & $\begin{array}{c}\text { Normal } \\
\text { distribution }\end{array}$ \\
Control & 7,114 & 3,7001 & 0,177 & 0,1498 & $\begin{array}{c}\text { Non-normal } \\
\text { distribution }\end{array}$ \\
\hline
\end{tabular}

Table 2 and 3 show that there is a significant difference between experimental and control classes. The normality test presented in Table 3 reveals that the control class is not normally distributed. Thus, data analysis used to test the differences between the two groups was the Mann-Whitney test. The results of the data analysis concluded that there are differences between group using PCL and those using conventional learning.

The calculation under Mann Whitney test gives $U_{1}=364,5$ and $U_{2}=860$, so $U_{\text {count }}=364,5$. In addition, the number of students in the experimental and control classes were $35(>20)$, hence the calculations were done using the normal curve approach with $Z_{\text {count }}=-2,913$. This indicates that there is an effect on students' mathematical critical thinking ability after being given treatment.

The learning process using the PCL approach does not only present authentic (nonroutine) problems, but there are several stages which characterize the learning process with this approach. In PCL process, students do the worksheet individually. This activity provides opportunities for students to develop their own knowledge. In addition to that, students' critical thinking ability will also be formed when students can construct their own knowledge. In this activity students are responsible for their respective tasks, so that students can build self-regulated learning. Students who find difficulties in individual work can consult the teacher to solve problems. This activity makes students active in the learning process.

While in group activities with peers, students will learn how to share or exchange their ideas about solving problems that have been done individually. In this process, students can build their critical abilities together in solving problems. To support this 
process, researchers also give guidance and direction in discussion activities in each group to avoid misunderstanding in solving problems.

Furthermore, in class discussion, students from other groups are encouraged to give the response to the solutions presented. This certainly will give students the widest opportunity to share their opinions to reach a mutual agreement that leads to the right solution with the guidance from the teacher. This class discussion activity trains students to express their opinions or ideas in public sphere. The benefit of this stage is that it can foster active character of the students.

Other benefit from this class discussion activity is that it trains the confidence of students to speak in front of the class, because most students are not confident to present the results of the discussion in front of the class. This happened at the first meeting of the study, no one dared to go forward to present the results of the discussion. The researcher finally decides to give additional value to students who present in front of the class. This method succeeded in making students have enough confidence to come forward to present the results of the discussion. Students are getting more confident in talking or expressing arguments or opinions in front of the class, so that students' mathematical critical thinking abilities are built.

The learning process using the PCL approach received a good response from the experimental class students. Students are very enthusiastic about learning, and students answer questions from researchers well. However, there are also students who do not pay attention to class lessons. The researcher also rebuked the students and asked them questions about the things that had been explained. Some students could answer and some could not.

The success of PCL to improve the learning process was also shown by several research results. Gardner \& Belland (2017) showed that learning using PCL gives significant results than traditional methods in students' problem solving abilities. Siregar, Novitasi, \& Agustina (2019) in their research on high school students showed that learning with PCL was able to improve mathematics literacy skills and student learning activeness. Furthermore, Rinaldi \& Afriansyah (2019) also showed that the mathematical problem-solving ability of students who got the model centered learning problem was better than those by problem-based learning

Hmelo-Silver in Potvin, Riopel, Masson, \& Fournier (2010) stated that meta analyses of the effects of problem centered approaches to student learning usually report that such pedagogical approaches are generally beneficial for students. Potvin et al. (2010) suggests that while this type of research does not always clarify what qualifies as "problem centered", it seems to have a positive effect on explanation construction skills, knowledge about the nature of science, motivation and responsibility, and metacognitive and reflective skills. This shows that the problem centered learning approach will have a positive impact not only on cognitive aspects but also on students' skills, affective, and metacognitive.

The success of the learning process can be achieved by making improvements from mistakes that have occurred. These errors can be known through the results of reflection activities. Reflection is given to students by giving questions such as what difficulties are faced in learning mathematics today, how to learn mathematics today, and others. The reflection is on the last sheet of the student worksheet given at each meeting. Based on the results of reflections given by students, they felt a difficulty in answering questions in the student worksheet. Students' difficulties in working on student worksheet only occur at the beginning of the meeting. This can happen because students were not used to the given non-routine questions. The results of reflection on the third, fourth and so on meetings show students have begun to adapt to the given questions. Students also feel that mathematics learning which is applied is more useful than before. 
The last meeting of this research activity was to conducta final test using instrument of mathematical critical thinking ability consisted of 6 questions. The following is an explanation of the analysis of answers to students' instruments of mathematical critical thinking abilities of students from both classes.

The treatment given to the experimental class has a significant influence on the students' critical thinking ability. This can be seen from the results of the post-tests that have been given to both classes i.e. the experimental class and the control class. The analysis of students' answers is discussed in the following explanation.

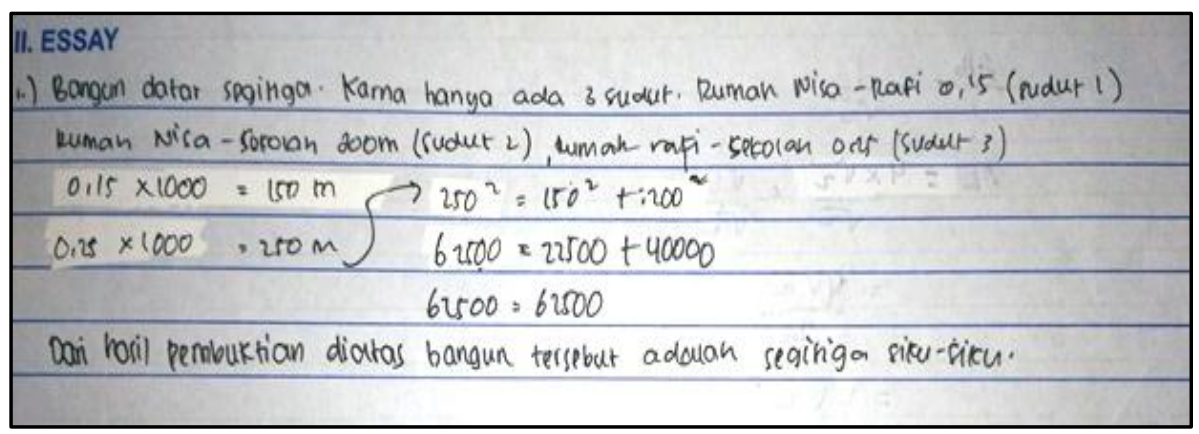

Figure 2. Students' answer in the experiment class

Translate of Figure 2:

The plane is triangle, because there are only 3 corners. The distance between Nisas' house until Rafi's house is 0.15 ( $1^{\text {st }}$ corner $)$, the distance between Nisas' house to school is $200 \mathrm{~m}\left(2^{\text {nd }}\right.$ corner $)$, the distance between Rafi's house to school is 0.25 ( $3^{\text {rd }}$ corner $)$. So,

$$
\begin{gathered}
0,15 \times 1000=150 \mathrm{~m} \\
0,25 \times 1000=250 \mathrm{~m} \\
250^{2}=150^{2}+200^{2} \\
62500=22500+40000 \\
62500=62500
\end{gathered}
$$

Based on the results, it is proven that the plane is a right triangle

Figure 2 shows the answers to the experimental class students in question number 1 according to the indicators of students' mathematical critical thinking ability. The student answers by giving his opinion, then continues by giving reasons supported by an argument. The argument given is the step to calculate the Pythagorean Theorem to prove that the opinion given is correct. The Problem Solving given by these students is very appropriate with the indicators of mathematical critical thinking. Indicator of mathematical critical thinking ability in question number 1 is to provide arguments and reasons for answering and solving questions. This also proves that these students have reached the indicator.

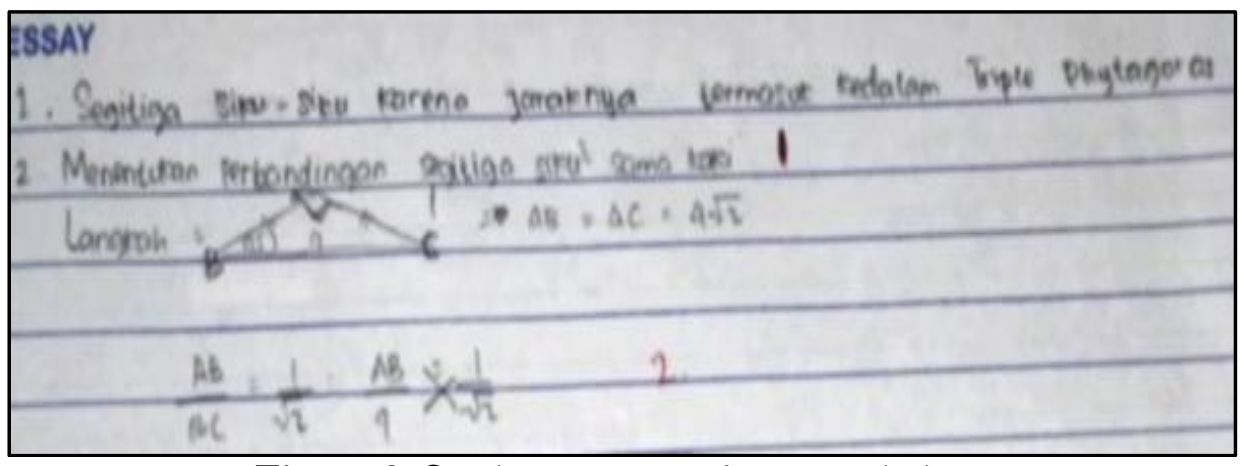

Figure 3. Students answer in control class 
Translate:

1. The triangle is the right triangle because the distance fulfills the requirement of Pythagorean triple

2. Determine the comparison of right-angled equilateral triangle

Figure 3 shows the answers of the control class students in question number 1 . The student is correct in giving opinions and reasons for the problems given, but students have not provided an argument that can support the opinions given. This shows that students do not think deeply to solve a problem. Based on the analysis of the questions in number 1, the two answers are true. Both answers get a score of 4 (maximum score). The researcher gave the maximum score based on consideration to the answers to the control class students. The reason the researchers gave maximum scores to control class students was that the students had given strong reasons by stating that the distance from the three position points on problem number 1 included three digits from triple Pythagoras. The student error is not displaying the results of calculations which indicate that the three numbers are really triple Pythagoras.

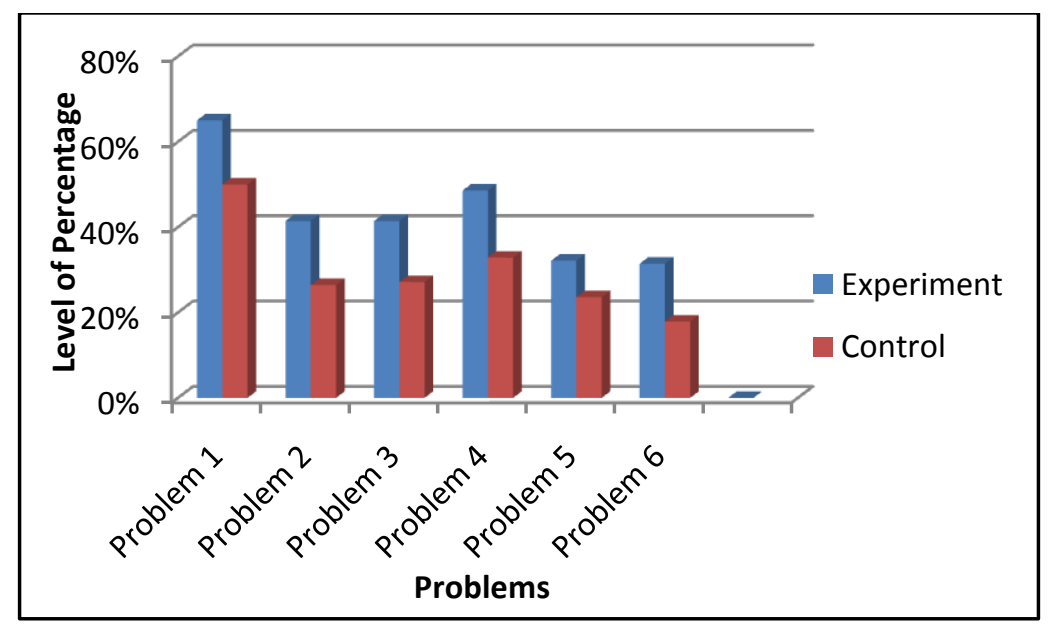

Figure 4. Percentage of Indicators of Mathematical Critical Thinking Ability

Based on the results of the graph in Figure 4, it appears that the experimental class reaches higher percentage than the control class in each instrument question mathematical critical thinking ability given to students. The results of students' critical thinking ability scores from both classes will be analyzed to measure the average score on each indicator. The average score on each indicator shows that the experimental class has a higher average than the control class. It is also proven that student responses are indeed very good towards problem centered learning approaches. Students also show significant changes at each meeting. The following are the average scores on each item indicator about the students' mathematical critical thinking ability between the experimental class and the control class.

Table 3. Recapitulation of Students' Mathematical Critical Thinking Abilities

\begin{tabular}{cccc}
\hline Class & Maximum Score & Average Score & Average Value \\
\hline Experiment & \multirow{2}{*}{24} & 10,4 & 43,33 \\
Control & & 7,114 & 29,64 \\
\hline
\end{tabular}

Based on the result in the Table 3, the average score of experimental class is higher than control class which is shown by some students in control class still have a low level in mathematical critical thinking ability. Consequently, students who have low 
mathematical critical thinking ability will affect the learning process. Therefore, mathematical critical thinking ability must be improved continuously.

This result is confirmed by Yuliati (2013) who states that critical thinking ability can be taught by involving practical session. Students are able to build mathematical critical thinking ability by training their rational thinking processes and figuring out the realworld problems. Moreover, developing students' critical thinking ability can be done by applying an interactive learning process. As a result, teachers have to produce an interactive learning process by applying an appropriate learning approach.

A study conducted by Azizah, Aeni, \& Maulana (2017) shows that the students who have participated in learning activities with problem-centered learning approaches feels happy to learn mathematics because they frequently involve in learning activities and are able to solve problems using learning-centered approach stages. The results of the study also prove that students' experience significantly improves after involved in the problemcentered learning approach. This indicates that the problem-centered learning approach affects students' mathematical critical thinking ability.

\section{Conclusion}

The strategy for improving students' critical thinking ability is by changing the learning process through interactive learning. In interactive learning process, it is necessary to present non-routine problems in order to improve students' mathematical thinking ability. The learning process can be realized by choosing the appropriate learning model or approach. The problem-centered learning (PCL) approach is the learning approach which is problem-centered. The PCL approach is one of the appropriate learning approaches to build students' mathematical critical thinking because presents non-routine problems that are solved through several stages, so students build their own knowledge by evaluating the evidence or decisions that have been taken in solving the problem. The PCL approach has three stages that direct students to be interactive in the learning process and through discussion students can provide arguments and reasons in answering and solving problems, so it can be concluded that there is an influence of the PCL approach to students' critical thinking ability.

\section{Acknowledgement}

An earlier version of this paper entitled "The Effect of a Problem Centered Learning Approach on Student's Mathematical Critical Thinking in Junior High School" was presented at the Konferensi Nasional Penelitian Matematika dan Pembelajarannya (KNPMP) IV 2019 held by Department of Mathematics Education, Universitas Muhammadiyah Surakarta, Indonesia, $27^{\text {th }}$ March 2019.

\section{Bibliography}

Aizikovitsh-Udi, E., \& Cheng, D. (2015). Developing Critical Thinking Skills from Dispositions to Abilities: Mathematics Education from Early Childhood to High School. Creative Education, 06(04), 455-462. https://doi.org/10.4236/ce.2015.64045

Arsisari, A. (2018). Penerapan Pendekatan Problem Centered Learning untuk Meningkatkan Kemampuan Berpikir Lateral dan Persistence (Kegigihan) Matematis Siswa di SMP. Inspiramatika, 4(2), 27-38.

Azizah, A., Aeni, A. N., \& Maulana, M. (2017). Pengaruh Pendekatan Problem-Centered Learning Terhadap Kemampuan Pemecahan Masalah dan Disposisi Matematis Siswa. Jurnal Pena Ilmiah, 2(1), 861-870. https://doi.org/10.17509/jpi.v2i1.11105

Dewanti, S. S. (2009). Perpaduan PCL dan Pelatihan Metakognitif dalam Meningkatkan Kemampuan Memecahkan Masalah Matematikan. Jurnal Penelitian Dan Evaluasi 
Pendidikan, 13(1), 21-39. https://doi.org/10.2147/PHMT.S95054

Dewi, F. (2015). Proyek Buku Digital: Upaya Peningkatan Keterampilan Abad 21 Calon Guru Sekolah Dasar Melalui Model Pembelajaran Berbasis Proyek. Metodik Didaktik : Jurnal Pendidikan Ke-SD-An, 9(2), 1-15.

Ennis, R. (2011). Critical Thinking: Reflection and Perspective Part I. Inquiry, 26(No.1), 4-18.

Gardner, J., \& Belland, B. R. (2017). Problem-Centered Supplemental Instruction in Biology: Influence on Content Recall, Content Understanding, and Problem Solving Ability. Journal of Science Education and Technology, 26(4), 383-393.

Handyani, I. (2015). Use of a Method Model to Improve The Ability to Solve Mathematical Problems of Elementary School Students. Journal of Basic Education Innovation, 1(No 1), 2.

Hendryawan, S., Yusuf, Y., \& Wachyar, T. Y. (2017). Analisis Kemampuan Berpikir Matematis Siswa SMP Tingkat Rendah Pada Pembelajaran Berbasis Masalah Dengan Green's Motivational Strategies. AKSIOMA: Jurnal Matematika Dan Pendidikan Matematika, 8(2), 50-58.

Nuriadin, et al. (2015). Enhancing of Students' Mathematical Reflective Thingking Ability Through Knowledge Sharing Learning Strategy In Senior High School. International Journal of Education and Research, 3(No. 9), 257.

Permendiknas. (2006). Standar Kompetensi Lulusan untuk Satuan Pendidikan Dasar dan Menengah.

Permendiknas. (2007). Standar Kualifikasi Akademik dan Kompetensi Guru.

Potvin, P., Riopel, M., Masson, S., \& Fournier, F. (2010). Problem-centered learning vs . teaching-centered learning in science at the secondary level: an analysis of the dynamics of doubt. Journal of Applied Research and Learning, 3, 1-24.

Putri, F. M., Darmawijoyo, \& Susanti, E. (2018). Kemampuan Berpikir Kritis Matematis Siswa Dalam Pembelajaran Matematika Menggunakan Teori Apos Pada Siswa Kelas Viii.1 Smp Negeri 6 Sekayu. HISTOGRAM: Jurnal Pendidikan Matematika, 2(1), 1. https://doi.org/10.31100/histogram.v2i1.29

Rinaldi, E., \& Afriansyah, E. A. (2019). Perbandingan Kemampuan Pemecahan Masalah Matematis Siswa antara Problem Centered Learning dan Problem Based Learning. NUMERICAL: Jurnal Matematika dan Pendidikan Matematika, 3(1), 9-18.

Ruseffendi. (2010). Educational Research Basics and Other Exact Fields. Bandung: Tarsito.

Setiawan, J., \& Royani, M. (2013). Kemampuan Berpikir Kritis Siswa SMP dalam Pembelajaran Bangun Ruang Sisi Datar dengan Metode Inkuiri. EDU-MAT: Jurnal Pendidikan Matematika, 1(1), 1-9. https://doi.org/10.20527/edumat.v1i1.637

Siregar, M. L., Novitasi, W., \& Agustina, L. (2019). Upaya Meningkatkan Kemampuan Literasi Matematis Siswa Melalui Penerapan Model Pembelajaran Problem Centered Learning (Pcl) di SMA Negeri 1 Angkola Barat. Eksakta: Jurnal Penelitian dan Pembelajaran MIPA, 4(1), 73-76.

Yuliati, L. (2013). Efektivitas Bahan Ajar IPA Terpadu Terhadap Kemampuan Berpikir Tingkat Tinggi SiswaSmp. Jurnal Pendidikan Fisika Indonesia, 9, 53-57. 